\title{
Dedication to Professor Rex Tregilgas Prider, 1910-2005
}

\author{
J. C. Bevan ${ }^{1}$ - L. G. Gwalani ${ }^{2}$ - A. L. Jaques ${ }^{3}$ - P. J. Downes ${ }^{4} \cdot$ N. V. Chalapathi Rao ${ }^{5}$
}

Published online: 30 January 2016

(C) Springer-Verlag Wien 2016

Professor Rex Tregilgas Prider was born on September 22nd, 1910 in the country town of Narrogin, Western Australia, and died in Perth aged 95 on October 6th, 2005. He was the first WA-born student of the University of Western Australia to occupy one of its chairs when he was appointed Professor of Geology in 1949.

Although Prider graduated from the University of Western Australia with a double major in Chemistry and Geology, and First-Class Honours in Geology, it was during the Great

J. C. Bevan

Jenny.Bevan@uwa.edu.au

L. G. Gwalani

lgwalani@gmail.com

A. L. Jaques

lynton.jaques@anu.edu.au

P. J. Downes

Peter.Downes@museum.wa.gov.au

N. V. Chalapathi Rao

nvcr100@gmail.com

1 School of Earth and Environment (M004), 35 Stirling Highway, Crawley, WA 6009, Australia

2 Copper-Gold-Fluorite Research Project, KRCL-University of Western Australia, c/o Ms. Shradha L. Gwalani, Boronia 26/122 Mounts Bay Road, Mounts Bay Village, Perth, WA 6000, Australia

3 Research School of Earth Sciences, Australian National University, Canberra ACT, Australia

4 Western Australian Museum, Locked Bag 49, Welshpool DC, WA 6986, Australia

5 Electron Probe Micro Analyzer (EPMA) Laboratory, Centre of Advanced Study in Geology, Institute of Science, Banaras Hindu University (BHU), Varanasi 221005, India
Depression when employment was scarce, and he began his working life cleaning boilers at the South Kalgurli Goldmine in 1932. However, eventually he rose to the position of assistant underground surveyor and was able to make use of his geological knowledge. In 1934 he returned to the University as Assistant Lecturer under Professor E. de C. Clarke. Clarke encouraged further study, and Prider spent 1937-38 in England as a Hackett Research Student at the University of Cambridge, working under Professor C.E. Tilley. Prider's ground-breaking research on the potassium-rich leucite lamproites from the Canning Basin of Western Australia resulted in his being awarded a PhD. In the course of his studies he discovered, analysed and named two new minerals wadeite $\left(\mathrm{K}_{2} \mathrm{ZrSi}_{3} \mathrm{O}_{9}\right)$ after the geologist Arthur Wade who brought the lamproites to his attention and, later, noonkanbahite $\left(\mathrm{NaKBaTi}_{2} \mathrm{Si}_{4} \mathrm{O}_{14}\right)$ after the sheep station on which many of the lamproites are found. Prider also described a potassic amphibole, which he named 'magnophorite' but this name was subsequently abandoned in later revisions of amphibole nomenclature. On returning to the University of Western Australia in 1939 he was appointed Lecturer in Geology, and in 1949 he succeeded Clarke as Professor and Head of the Department of Geology, a position he held until he retired in 1975 .

Much of Prider's research was on the Precambrian rocks of the Yilgarn Craton, and he published thirty-eight papers in scientific journals, including Nature, on a wide range of WA-related topics. However, he was probably best known internationally for his work on the leucite lamproites of WA, particularly his 1960 paper (Prider 1960) in the Journal of the Geological Society of Australia which emphasised the remarkable similarity of the lamproites in chemistry and mode of formation to kimberlites (then the only known igneous host-rocks of diamonds), thus implying the possibility of economic diamond occurrences in the Kimberley region. This 
concept sowed the seeds for the exploration for diamonds in WA in the late 1960s, but vindication of Prider's concept had to wait until the discovery of the concealed diamondiferous olivine-rich lamproites in the Ellendale area at the northern margin of the Canning Basin in 1976 (Jaques et al. 1986; Smith et al. 1990; Ahmat 2012). This was followed in 1979 by discovery of the major Argyle diamond deposit - also olivine lamproite - with diamond mining commencing in 1983. Interestingly, his 1960 paper had been rejected when first submitted to the Journal some years before, on the grounds that it was of local interest only. Later, when he was made President of the Geological Society of Australia, he retrieved the paper, used it as his Presidential Address and thus guaranteed its publication: the work is now regarded as a milestone contribution in this field. Fittingly, Prider (then Emeritus Professor at UWA) gave the opening address at the Fourth International Kimberlite Conference held in Perth in August 1986. Many congress attendees participated in the post-conference excursion to the Kimberley region to see first-hand the leucite lamproites studied by Prider, and the then newly-discovered olivine lamproites at Ellendale in the West Kimberley and at Argyle in the East Kimberley.

Rex Prider was a hands-on professor who had a remarkable memory for students. He made a point of lecturing to first-year students and supervising their laboratory classes where he got to know and encourage the students personally. He maintained that fieldwork both revealed and formed a student's character, and ran rigorous and spartan geological field camps for students. His students were introduced to the world of geology through his lectures and his huge collection of Kodachrome slides: many went on to graduate and take up careers in geology, including one of us (ALJ). He co-authored two elementary geological texts for students and also edited a book on mining in Western Australia. An unpretentious man, he never lost his country accent, was very approachable, and had a robust sense of humour.

He served twice as President of the Royal Society of Western Australia (in 1944-45 and 1959-60) and was awarded the Society's medal for research in 1970 . When a national Geological Society was formed, he became inaugural chairman of the Western Australian Division (1952), and later Federal President (1958-59). He was also Federal President of the Gemmological Association of Australia (1967-70). The Prider Medal, a gold medal presented each year to the student completing the degree of Bachelor of Science with Honours in Geology showing the greatest aptitude for research, is given in his honour. In addition, the mineral priderite $\left([\mathrm{K}, \mathrm{Ba}]\left[\mathrm{Ti}_{1}, \mathrm{Fe}^{3+}\right]_{8} \mathrm{O}_{16}\right.$, an accessory mineral in leucite lamproite), and the Cretaceous fossil Anomia prideri, are named for him, as is the Rex Prider Court adjoining the Geology buildings on the main campus of the University of Western Australia.

He retired as Professor in 1975 but continued to live near to, and support, the Geology Department and Museum (Fig. 1).

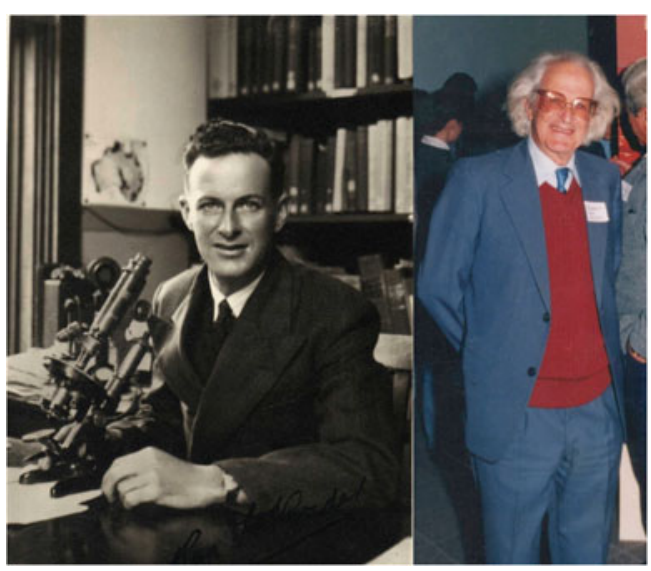

Fig. 1 Rex Prider at the microscope in 1948 (left), and at the University of Western Australia in 1988 (right). Photographs courtesy of the University of Western Australia

Research on alkaline igneous rocks continued for a time at UWA under the leaderships of the late Associate Professor N.M.S. Rock and Professor D.I. Groves.

Rex Prider married Catherine Esther Walton, whom he met in Kalgoorlie, in 1936 and they had two children, a son, Rodney (an outstanding Classics scholar, who sadly predeceased his parents), and a daughter, Bobbie. His wife died in 2000. In 2004, he was awarded the Chancellor's Medal of the University of Western Australia, presented partly in recognition of the personal help that he and Mrs Prider gave throughout his long career at UWA to enable Colombo Plan Asian students to integrate successfully into University life. He retained to the end the respect and friendship of fellow staff members, and of a large group of former students who had come under his influence.

Below are a list of publications by Rex Prider and coworkers on the leucite lamproites of West Australia, together with references relating to Prider's contribution to stimulating diamond exploration in Western Australia. This Preface has drawn on the published obituary for Professor R.T. Prider by Dr J.E. Glover, formerly of the UWA (Glover 2005).

\section{References}

Ahmat AL (2012) The Ellendale diamond field: exploration history, discovery, geology and mining. Aust Gemmol 24:280-288

Glover JE (2005) Obituary: professor Rex T prider. J Roy Soc Western Aust 88:197

Jaques AL, Lewis JD, Smith CB (1986) The kimberlites and lamproites of Western Australia. Geol Surv Western Aust Bulletin 132, 268 pp

Smith CB, Atkinson WJ, Tyler EWJ (1990) Diamond exploration in Western Australia, Northern Territory and South Australia. In Glasson KR and Rattigan JH (eds) Geological aspects of the discovery of some important mineral deposits in Australia. Australasian Institute of Mining and Metallurgy, Monograph 7:429-453 
Published works on the West Australian lamproites by Rex Prider and co-workers

Norrish K (1951) Priderite, a new mineral from the leucite lamproites of the west Kimberley area, Western Australia. Mineral Mag 29:496-501

Prider RT (1939) Some minerals from the leucite-rich rocks of the west Kimberley area, Western Australia. Mineral Mag 25:373-387

Prider RT (1960) The leucite lamproites of the Fitzroy basin, Western Australia. J Geol Soc Aust 6:71-118
Prider RT (1965) Noonkanbahite, a potassic batisite from the lamproites of Western Australia. Mineral Mag 34:403-405

Prider RT (1982) A glassy lamproite from the West Kimberley area, Western Australia. Mineral Mag 45:279-282

Prider RT, Cole WF (1942) The alteration products of olivine and leucite in the leucite lamproites from the West Kimberley area. Amer Mineral 27:373-384

Wade A, Prider RT (1940) The leucite-bearing rocks of the West Kimberley area, Western Australia. Quart J Geol Soc Lond 96:39-98 